\title{
Improved Teacher Performance Through Work Culture And Environment
}

\author{
Asma Lutfah ${ }^{1, a}$, Nunuk Hariyati $1, b$, Warih Handayaningrum ${ }^{2, c}$ \\ ${ }^{1}$ Department of Education Management, Postgraduate, State University of Surabaya, Surabaya, Indonesia \\ 2Department of Cultural Arts Education, Postgraduate, State University of Surabaya, Surabaya, Indonesia \\ a asmalutfah2@gmail.com; b nunukhariyati@unesa.ac.id; c warihsendratasik@yahoo.com; \\ ${ }^{*}$ Corresponding Author
}

How to Cite: Lutfah, A., Hariyati, N., Handayaningrum, W. (2019). Improved Teacher Performance Through Work Culture And Environment. International Journal for Educational and Vocational Studies, 1 (8), 859-863. DOI: https://doi.org/10.29103/ijevs.v1i8.2240

\section{ARTICLE HISTORY}

Received: 6 September 2019

Revised: 8 October 2019

Accepted: 2 November 2019

\section{KEYWORDS}

Teacher Performance;

Work Environment;

Work Culture;

\begin{abstract}
The existence of teachers in the world of education has a great influence to produce excellent students. Based on the law Republic of Indonesia Number 14 of 2005 about Teachers and Lecturers, who stated that teachers and lecturers have functions, roles, and a very important position in national development in the field of education, so it needs to show that its performance can be accounted for. Performance improvement is closely related with the problem of how to increase teacher motivation, how to develop an effective work culture as well how to create a work environment that is comfortable and conducive, so that the teacher can and is willing to work optimally. According to Nitisemito (1991: 184-196), influencing factors work environment is coloring, cleaning, lighting, air exchange, music, safety and noise. while work culture factors that influence are: (1) conditions the physical environment of work, such as giving awards, giving welfare, fulfilling infrastructure and facilities. (2) working environment conditions, such as support in carrying out tasks, communication and interactions with peers, people student parents, principal and public. For that, schools must be able creating a conducive work environment and work culture.
\end{abstract}

This is an open access article under the CC-BY-SA license.

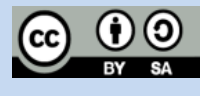

\section{INTRODUCTION}

Human resources are part of an advance in science, development and technology. Limited human resources make an organization or institutional institutions are required to be able to optimize and produce competent human resources, have high morale and discipline so that organizational goals are achieved. Basically there are various factors that can affect the success of education, such factors: teachers, students, facilities and infrastructure, curriculum and educational environment.

Teacher professionalism is characterized by expertise in the field education. According to Law No. 14 of 2005 article 20, duties or obligations teacher, among others: 1) plan learning, implement quality learning processes, as well assess and evaluate learning outcomes; 2) improve and develop academic qualifications and competencies in a manner sustainable in line with the development of science, technology and art; and 3) acting objectively and not discriminatory on the basis of gender considerations, religion, or family background of the socioeconomic status of students in learning.
Important problems experienced by the leaders at this time is how can improve the performance of its employees so they can support success in achieving goals. According to Schermerharn (2003:7) that leadership or a good manager is capable create a condition so people individually or in groups can work and achieve high performance. Manulang (1998) explains that motivation is a driving force for employees/educators to work hard. from that motivation can be seen the results of work performance/performance. Teacher performance is the teacher's perception on teacher work performance related with quality of work, responsibility, honesty, cooperation and initiative. Compensation given to the teacher is very influential at the level of job satisfaction, work motivation, and work result.

Factors that affect performance employees or teaching staff is a work environment. According to Nitisemito (1991:184-196), influencing factors work environment is coloring, cleaning, lighting, air exchange, music, safety and noise. Other than that which has a role in an effort to improve performance is work culture. Work culture can be 
seen with low levels of appreciation for employee performance, low levels welfare, communication and interaction between employees, guardians of students/parents, leaders and the community there is still a distance or boundary, so it looks less harmonious (Hoy, 2001: 189). At the Foundation Special Education, work culture deemed not good. Special Education Foundation can attention to the problem of work discipline factors that are still low, the environment work less comfortable, and a work culture can not develop effectively so that the performance of employees or personnel instructors who are expected to be realized well.

Efforts that can be made to improve teacher performance, among others: 1) accept the teacher well; 2) give new teaching assignments according to the fields and competencies that are mastered by the teacher; 3) forming and organizing groups teacher work in the field of study and deliberation teacher similar field of study (MGMP) as a forum for teachers to discuss planning problems and solve problems that occur in the classroom; 4) conduct administrative supervision and academic to teachers as material improvement and determine policies; 5) provide guidance with good administrative, academic, and career teachers; 6) give the teacher a chance to participate good training conducted in schools, district, province or at the level national; 7) give a gift (award) to teacher who achieves and gives a punishment in teachers who are lazy and problematic; 8) giving additional tasks to the teacher; 9) make family ties in each school with meetings held at home of family ties.

From some of these factors, the teacher in teaching and learning in schools occupy a very important position. In some studies found that teachers have an important role in spite of the limited facilities and infrastructure. The study in 16 developing countries, teachers contribute to students achievement by $34 \%$, management contributed $22 \%$, while the influence of infrastructure by 23\%. Furthermore, Supriya (Mahmudi, 2007) in his research found that $76.6 \%$ of student learning outcomes are influenced by the performance of teachers, with details: the ability of teachers to teach at $32.43 \%$, mastery of the subject matter of $32.38 \%$, and the attitudes of teachers towards subjects gave a contribution of $8.60 \%$. From some of the research findings can be said that the performance of teachers affects student achievement. Evidence from the field suggests that performance is affected by many factors, among others: organizational culture, motivation, and job satisfaction.

Westover et al (2010) stated that job satisfaction is the main concern management in many modern organizations. Wright and Bonett (2007) observed that workers with higher levels of job satisfaction would do it display a downward trend in finding work and a downward tendency to leave organization. In the same way, employees who perceive their needs as unmet are growing in general dissatisfaction and becoming increasingly attracted to competing workplaces. However, the most accepted and general aspect of job satisfaction is satisfaction with salary, promotion opportunities, coworkers, supervision, and the work itself.

Westover and Taylor (2010) observed that turnover seems to be a major problem for many organizations indeed a very important issue because of the costs associated with recruiting and train new personnel. But rewards, especially intrinsic rewards, are interesting employment and job autonomy, were found to be the main drivers of job satisfaction for most countries.

\section{METHODS}

This article is a literature study by examining journals related to improving teacher performance through culture and work environment. The results of various studies of this literature will be used to describe the problems of teacher performance related to culture and work environment.

\section{RESULTS AND DISCUSSION}

\subsection{Teacher Performance}

Performance means about what to do, how to do and the results achieved from such work. Performance is basically working strived to achieve the performance to produce a specific output within a predetermined time. Performance as the embodiment of the work on the job, activity and behavior within the specified time limit. Waldinan (1994) explains that the performance is the combined behavior of the achievements of what was expected to be a choice or part of the terms of an existing task on each individual in the organization. Performance can also be defined as the result of the quality and quantity of work that can be achieved by a person carrying out the duties of employees in accordance with the responsibilities given to him. Meanwhile, Armstrong \& Anggela (1998) interpret the performance of the broader sense, not only regarding work, but also how the work process directly. The performance is about doing the job and how the results achieved from the work, which has a strong relationship with the organization's strategic objectives, customer satisfaction and economic contribution.

Basically teacher performance is achievement which appears as a form of success work on someone. Success performance is also determined by work and one's ability in the field. Work success is also relatedwith one's job satisfaction (Mangkunegara, 2000: 67). According to Usman (2003: 10-19) to measure performance teaching staff there are indicators namely: (1) ability to plan learning teaching, including: mastering the outlines of the administration of education, adjusting the analysis of subject matter, compiling semester programs, compiling programs or learning, (2) abilities carrying out teaching and learning activities, include: pre-instructional stage, instructional stage, evaluation and follow-up stages, and (3) ability to evaluate, including: normative evaluation, formative evaluation, report evaluation results, implementation of improvement and enrichment programs. Meanwhile, according to Rivai \& Basri (2005: 
16-17) several factors which affect the performance of them work discipline, work environment and culture work.

In the traditional performance appraisal system, performance is only associated with the personal factors. However, in reality the performance is often caused by factors beyond personal factors, such as leadership, team and others. In this regard, Campbell (1990), explains that there are many functional relationship between performance and performance attributes, such factors: knowledge, skills, motivation. In building an effective performance and build personal compliance in work organization, these factors are standard operating procedure that must be followed in order to build a culture of work and an understanding of the working culture itself. This understanding will give birth to motivation and job satisfaction.

Teacher performance assessment aims to obtain information about teacher performance in the past and predict the teacher's performance in the future. According to Alwi theoretically the purpose of assessment is categorized as a evaluation and development evaluation among others (Risnawatiririn, 2012): (1) assessment results are used as a basis for compensation; (2) results assessment is used as a staffing decision; (3) assessment results are used as a basis evaluating the selection system. While the development appraiser must complete: (1) the real achievements of the individual; (2) individual weaknesses which impedes performance; achievements developed.

Results of performance evaluation the teacher is useful as an input in the preparation of the professional development program sustainable. In addition, the results of teacher performance assessment are also useful in determining acquisition of teacher credit scores in teacher career development. Ministry of National Education mention some of the benefits of teacher performance assessment as follows (Ardiansyah, 2011): 1) staff development through in-service training, 2) career development through in-service training, 3) improved relations between staff and leaders, 4) more in-depth knowledge about school and the person, 5) productive relationship between assessment and planning and development school, 6) better learning opportunities for students, and 7) improved school morale and efficiency.

Important strategies that can be taken to improve teacher performance, namely training and performance motivation. Training is used to deal with the lows teacher ability, while performance motivation is used to deal with the low enthusiasm and passion for work (Sinambela, 2012:213). Training will take place optimally if designed according to needs, the right method and time. The training is very suitable for teachers who have potential high but still weak in knowledge and skills. whereas according to Iskandar (2011), the motivation for working better is needs that lead to an action act (behavior) which aims to meet those needs (goals). In other words, needs are the basis of human actions.

\subsection{Work Environment}

The work environment itself is compliant Nitisemito (1991: 183) is everything that is around workers and can affect him in running tasks that are charged. The work environment indicators are as follows: coloring, cleanliness, lighting, air exchange, music, security and noise. The elements of the work environment according to Kartono (1995: 161) is speech said among the workers, the attitude of helping to help, the attitude of reprimanding each other and correcting mistakes and family attitudes among workers.

While the circumstances are support the work environment according to Nitisemito (1991: 192) is a work atmosphere a fun, authoritarian level boss employees at work, the level of source advice in groups, opportunities for develop their talents, peace, and the room or place where it works. The work environment will determine a person's comfort at work. More and more good work environment will lead to the achievement of organizational performance maximum.

This was proven by Trisno \& Suwarti (2004) who conducted the study about the analysis of the influence of the work environment on the performance of government officials, from the results showed that the work environment had a positive and significant effect on performance. Obineli (2013) argued that inspired workplace will result in inspired workers and draws attention to the importance for work performance, the atmosphere, quality and style of buildings and offices. environment conditions enhance working. Such conditions like suitable temperature, humidity, ventilation, lighting, cleanliness of the workplace and adequate tools and equipment (such as public address system, computer, resource materials for teaching, good offices) are important in job satisfaction. Good working conditions provide greater physical comfort for teachers and boost their morale.

Okonkwo and Obineli (2011) stressed that many teachers in public schools lack motivation and job satisfaction because of poor salary and the poor condition of the environment of their workplace. This is because a workplace environment with essential facilities is a prelude to job satisfaction among workers. If secondary school teachers are well paid, they can still go an extra mile (like the research subjects) to ensure that they have a stimulating project working environment.

\subsection{Work Culture}

Work culture is a philosophy based on the view of life as values that become the nature, habits and driving forces, entrenched in the life of a community group or organization, then reflected from attitudes into behavior, beliefs, ideals, opinions and actions that manifest as "work" or "work" (Triguno, 1995: 3). Work culture culture indicators instructors are as follows: (1) conditions the physical environment of work, including: awarding, giving welfare, fulfilling infrastructure and facilities. (2) working environment conditions, including: support in carrying 
out tasks, can be design and design work, supervision and work discipline, communication and interactions with peers, people student parents, headmasters and the environment community, chief leadership function school, establish policies in personnel, school programs according to nature and objectives, setting compensation policies and managing schools. In the opinion of experts work culture has an impact on job satisfaction based on socialization.

Successful socialization of work culture will further have a positive impact on employee job satisfaction while failure means a negative impact on employee job satisfaction. Culture strong work can create an atmosphere conducive work so that the quality of work will be enhanced which is the key success for an organization, where organizational success is an indicator of employee job satisfaction. Research Daryatmi (2005) concerning cultural influences work on employee performance can be concluded that work culture is influential positive on employee performance. From the description of the work culture. With thus, the third hypothesis proposed is that work culture has a positive effect on teacher performance.

Gordon and Ditomaso (1992) explain organizational culture is a shared attitude and perception in an organization that a bases on a set of basic norms and values and helps members understand the organization. Organization Culture is all attitudes and perceptions that arise as a result of a person's interactions with his work other people and with the environment, attitudes and perceptions that arise in the organization come from a set of values and norms that help member organizations to understand all aspects related to the workplace. Organizational culture is power, in organizations that are not seen, but can be felt and felt by it Members The results of this perception affect the behavior of members in doing work. While Robbins (2007) explains that organizational culture is a perception that exists in organizations, not in individual. As a result, individuals with different backgrounds or at different levels in the organization grow niche to describe organizational culture in smilar terms.

\section{CONCLUSION}

Organ and Bateman (1986), stating that the performance includes various behaviors about what to do, how to do it and the results of such work. Such behavior is more common to workers who are satisfied. So the job satisfaction has a significant connection with the performance of teachers. From the description it can be seen that, directly or indirectly, no significant relationship between organizational culture, motivation and job satisfaction with the performance of teachers. Proposition between these variables confirms that teacher performance can go up or down in relation to the increase or decrease in organizational culture, motivation and job satisfaction.

\section{REFERENCES}

Ardiansyah, Asrori. (2011). Strategic Steps to Improve Performance. Bandung: Teenagers Rosdakarya

Campbell, D. (1990). The Force Prejudice, The Gurdian, 31 October.

Collier, C. C. \& Walsh, W. J. (1971). Teaching in the Modern Elementary School. New York: The Macmillan Company

Chepyator, J (2013). Global Perspectives On Physical Education And After School Sport Programs. University of America, Lanham, Maryland.

Daryatmi. (2005) Effect of Motivation, Supervision and Work Culture of Employee.

Productivity in Regional Banks of Credit Companies Rakyat Karanganyar Regency.

Village Credit Agency.

Gordon, G. G. \& Ditomaso, N. (1992). Predicting Corporate Performance From Organizational Culture. Journal of Management Study, November 1992, 793-98.

http://dx.doi.org/10.1111/j.1467-6486.1992.tb00689.x

Hightower, A (2011). Improving Student Learning By Supporting Quality Teaching: Key Issues, Effective Strategies and Outcomes. McGraw Hill Publishers, New York.

Iskandar, Uray. (2011). Strategic Steps to Improve Performance. Yogyakarta: BPFE-UGM.

Kartono, K. (1995) Industrial Management. Bandung: Rajawali.

Kelly, S (2004). An event history analysis of teacher attrition: Salary, teacher tracking, and socially disadvantaged schools. Journal of Experimental Education. 72(3):195-220.

Kinman, G. Russell, K. (2001). The Role of Motivation to Learn in Management Education. Journal of Workplace Learning, 3(4), 132-149. http://dx.doi.org/10.1108/13665620110391088

Mangkunegara, AA. (2006). Performance Evaluation SDM (Cet. 10th). Bandung: PT. Refika Adithema.

Mahmudi. (2007). Public Sector Performance Management. Yogyakarta, College of Management Sciences, YKPN.

Nitisemito, U.S. (1991) Personnel Management. Jakarta: Ghalia.

Obineli, A (2013). Teachers' Perception of the Factors Affecting Job Satisfaction in Ekwusigo Local Government of Anambra State. Department of Guidance and Counselling Nnamdi Azikiwe University, Awka Anambra State, Nigeria.

Odhiambo, G (2008). "Elusive search for quality education: The case of quality assurance and teacher accountability", International Journal of Educational Management, 22(5), pp.417 - 431. 
Okonkwo, C and Obineli, A. (2011). The Roles of Counselling in Promoting Good Leadership: Anambra State on the Focus. A journal that cuts across all behavioural issues. 3 (2).

Organ, D. W. \& Bateman, T. S. (1986). Organization Behavior: An Applied Approach Psychological (Plano Tex: the Business Publication).

Robbins, S. P. (2007). Organizational Behavior. Edition Indonesian, Jakarta, PT. Index.

Schermenharn, J.R. (2003). Management (Edition Indonesian). Yogyakarta: Publisher Andi.

Sinambela, Lijan Poltak. (2012). Employee Performance: Measurement Theory and Implications. Yogyakarta: Graha Science.

Triguno. (1995) Work Culture. Jakarta: Holy mountain.

Trisno, I. \& Suwarti, T. (2004) "Analysis Influence of Compensation and the Environment Work on Apparatus Performance Government (Case Study of the District Industry and Trade Office Starch)". Scientific Journal of Management Studies, 1 (1).

Wright, B. E. (1989). Public Sector Work motivation: Review of Current Literature and Reversed Concional Model. Journal of Public Administration Research and Theory, 11(4), 3369-3830. 